\title{
Psychology of Lying
}

\author{
Farisha. A. T. $\mathrm{P}^{1}$, Sakkeel. K. $\mathrm{P}^{2}$
}

\section{ABSTRACT:}

Lying is a part of communication and a form of social behavior which is involved in interacting with others. Lying means saying a statement that he/she knows themselves as false to others to whom he/she want to perceive it as true. It can be explained by different psychological principles of psychodynamic theory, humanistic theory, behavior theory etc. Lying arises from hedonistic nature of humans that to avoid pain and to increase pleasure. It can be also seen that we lies not only for personal gains but also for others gain too. That is to avoid harm affecting ourselves and to avoid hurting others. Lying can be accepted if it saves someone's life-ourselves or of others.

Keywords: Psychological factors, Lie

\section{INTRODUCTION:}

Lying is a form of deceiving others verbally. It is a part of our behavioral response in communicating with others. It has long been a part of everyday life. We can't get through even a single day without telling lies. It is a consistent feature of human social behavior. We are not aware of all the lies we tell. We people lie most the time in our daily life, afraid of other people finding out the truth about us. We lie mostly to our parents, partners, friends, supervisors and so on to whomever else with whom we interact. We lie for many reasons. Sometimes to get rid of the troubles or sometimes to escape from the responsibilities. We think of the possible shame or threat occurring when the truth is revealed. So we find possible solutions in the form of lies. It is a lazy way to solve a problem. Research on the self-reported frequency of lying indicates that in the course of their normal daily activities, people lie in about $25 \%$ of their interactions with others (DePaulo \& Bell, 1996; DePaulo \& Kashy, 1998; Kashy \& DePaulo, 1996). The difference in lying only exists in its severity, the frequency and target or the reasoning behind the lies. Lie of omission can also be seen which means simply remaining silent with a deceptive intention. Lying can take two forms also, a response to short term issue which requires little planning and long term lying which requires much planning.

${ }^{1}$ (Lecturer in Psychology, School of Behavioral Sciences, Kannur University. Raz complex, Kakkad road, South Bazar- Kannur 670002., Kerala.

${ }^{2}$ Assistant Professor, Department of Psychology, WIRAS College, Kannur University. Kerala. 


\section{Psychology of Lying}

While going through the theoretical explanations of lying it was found that it was strictly and seriously studied by many researchers. The term lie literally means a deliberate untruth. Even though there is no universally accepted definition of lying (Kagan 1998), it is defined in many ways. The Oxford English Dictionary defines lying as making a false statement deliberately by someone who knows it is not true (Hawker, 2006). The most commonly accepted definition of lying that manages to avoid these problems is that a lie is an assertion, the content of which the speaker believes to be false, which is made with the intention to deceive the hearer with respect to that content (Williams 2002); or, more formally it is explained as a person lies when he asserts something to another which he believes to be false with the intention of getting the other to believe it to be true (Kupfer, 1982)

Dawson in his blog explains four different types of liars. The Occasional liars are those people who seldom lie. But when they do, they are blown away by their actions and feel guilty for what they have done. These types of people are the ones who are quick to seek forgiveness from the person they lied to. The occasional liars are not perfect, but are usually respected for their strong attempt at being a truthful person, and humble enough to admit their mistakes. If we were all honest with ourselves, we would have to admit we are at least an occasional liar. The Frequent liars are those who go about his/her life lying every which way. These types of people were not concerned about covering their tracks, or making sure their lie makes sense. Everybody knows these people are lying because they are sloppy with their lies. These persons have very few friends, because people get sick of his obviously twisted stories. Third type, the smooth liar is just what their description sounds like this person has become very smooth and skilled at telling lies. These liars are so good with words and body language people tend to believe them even when they know they have a reputation of being a liar. Yet, all the time, the smooth liar knows they are lying. These people are fun to be around, and very entertaining, but after being found out, the smooth liar tends to move on to others to whom they can apply their dark talents. Fourth type the compulsive liar lies when they don't have to, even if telling the truth makes more sense than the lies they tell. These people have an addiction to lying, and they simply cannot stop. They are out of control. They spend hours studying situations trying to come up with more lies that will allow them to maintain all their previous lies. These people are totally untrustworthy and end up unable to keep friends. A compulsive liar ends up a lonely, sad person who tragically lies the most to their own self (thehopeline.com).

The psychology of lying can be a complicated concept because people lie for different reasons. What induces a person to not tell the truth explains the causes for our lying behavior. While some people lie in an attempt to avoid punishment or to avoid hurting someone else's feelings, others lie out of impulse or because they want to present themselves as someone they are not. Motive for lying varies throughout our lifespan period also. During childhood children usually lies for pleasure and to escape from the punishments of parents or other authoritary figures. As we get older lying is found to have a survival value. That is we lie to protect ourselves from the 


\section{Psychology of Lying}

perceived threat to our existence or wellbeing. Inorder to ensure our safety we lie and hide the truth.

Motives or the reasons for lying behavior can be explained based on various concepts and theoretical foundations contributed by eminent theorists of psychology. There are many explanations for why people lie. Lying can be explained based on the psychoanalytic explanation of Sigmund Freud as the interplay of id, ego and super-ego. Ego is that level of mind which works according to the reality principle. Sometimes we are forced by our id to stay away from the reality since the reality evokes anxiety within us. We are afraid to face the reality and hence we hide the truth and we lies. When the ego cannot cope with some distressing stimuli it finds an alternative by making justifications through lying. Super-ego the moral arm of our personality may also have role in this. Super-ego wants us to be perfect in any sense. So in order to save us from imperfection we lie to make ourselves perfect in the eyes of others and in our own eyes too. That is, a kind of defense mechanism is working through, in deciding what to lie and how to lie. Lying can hide or alleviate conflicts or stresses that give rise to anxiety. Sometimes we are denying the truth from coming to our conscious mind or sometimes we are creating justifications for our undesirable or unacceptable behavior by making use of untruth statements.

From a bahavioristic point of view, it can be said that lying behavior patterns are acquired through learning like learning other simple and complex behavioral responses. Once the lying behavior of an individual is reinforced by favorable consequences, the behavior pattern gets repeated and becomes a part of behavioral repertoire. They repeat the same when they are in need of the same consequences.

Lying can also be explained based on the Maslow's hierarchy of need. According to his theory we have an innate tendency to move towards achieving our needs one after the other. Inorder to achieve these levels and to prevent the obstacles from coming way to our need satisfaction we make statements which may be not true. When we feel that we need to say a lie to get our food we lie. When we are satisfied with our food, our need goes further for need for belongingness. And if there arises any kind of hindrance of its satisfaction we make statements which facilitate our need satisfaction disregarding of whether it is true or false. Liars can also seem to possess high narcissistic traits. That is we all lies for our personal causes. So because of our excessive love for ourselves and to save ourselves from anxiety we lie.

It is a crucial question that whether a lie has a different neural pattern than a truth. Neuropsychologists know that there is a distinct difference in brain activity when a person tells the truth as opposed to when a person tells a lie. Different parts of the brain are used to deliberately tell a falsehood than are used to speak the truth, so from a neuropsychological viewpoint, there is a distinct difference between the two (Addiction.lovetoknow.com). In psychiatry, pathological lying, also called compulsive lying, is a behavior of habitual or compulsive lying (Dike, Baranoski, Griffith, 2005). It was first described in the medical literature in 1891 by Anton Delbrueck (Dike \& Charles, 2008) The individual may be aware they are lying, or may believe they are telling the truth, being unaware that they are relating fantasies. 


\section{Psychology of Lying}

There are mental disorders that may result in patients telling lies, but not realizing that what they are saying is not true. Examples include Paranoid Personality Disorder or some of the Dissociative Disorders (Addiction.lovetoknow.com).

In a meta-analytic study by Bond and DePaulo (2006), they examined the accuracy rates of lie detectors in 206 studies. They found that, on average, people were accurate in only $54 \%$ of their lie-truth judgments, whereas one would expect $50 \%$ accuracy by chance alone. Understanding the subtle indications of lying would certainly benefit anyone wishing to detect lying and deception in others.

Despite the rather unimpressive success most people have at lie detection, scientific investigations have uncovered a few noteworthy approaches to detecting deception. There is a rather long history of using physiological measures such as the polygraph to detect evidence of deception (Larson, 1927; Marston, 1917). More recently, researchers have attempted to use measures of brain activity to identify liars (Langleben, 2008). It should be noted that physiological measures are only indirect measures of lying and therefore questions about the validity of using them to detect deception remain (Honts, 1994; National Research Council, 2002; Spence, 2008).

In a study by Hart, Fillmore, \& Griffith in 2009 entitled Indirect Detection of DeceptionLooking for Change, the researchers examined the effectiveness of using indirect methods to detect liars. College students viewed a video in which half of the people told some lies and half of the people were entirely truthful. Participants were 104 (53 males, 51 females) undergraduate students at a small coeducational university in the southern United States. They were either asked to detect the liars in the video or they were asked to identify people in the video whose behavior, mannerisms, or speech changed. Participants using the indirect lie detection method of looking for behavioral change were more accurate in their categorizations of liars and non- liars than were participants who were directly and explicitly looking for liars. The study adds to a growing body of evidence that indirect lie detection strategies may offer some advantages in accuracy over more direct behavioral detection of deception (Anderson, 1999; Anderson, DePaulo, \&Ansfield, 2002; Granhag, 2006; Hurd \&Noller, 1988; Vrij, Edwards, \& Bull, 2001). This growing body of evidence suggests that if people can be disengaged from their stereotypedriven deception detection strategies, they might detect important and meaningful behavioral cues that would have otherwise gone unnoticed. So it will be vital to explore the variety of indirect approaches that might yield better detection of liars.

Researchers have examined verbal communication cues of deception. Speech cues such as pauses, voice pitch; interruptions, hesitations, latency to respond, and response length have been used to detect deception (Vrij, 1995; Vrij, Edward, \& Bull, 2001; Vrij, Edward, Roberts, \& Bull, 2000). The contents of speech such as descriptions of feelings, reproductions of speech, amount of detail, logical inconsistencies, and spontaneous corrections have also been found to vary with the veracity of statements (DePaulo, Lindsay, Malone, Muhlenbruck, Charlton, and Cooper, 2003; Vrij, Edward, Roberts, \& Bull, 2000). The validity concerns previously noted with 


\section{Psychology of Lying}

physiological measures also exist with the measures of speech cues. While certain variables of speech may change when one lies, those changes can and do occur for other reasons not tied to deception. Historically, humans have looked to non-verbal behavior for indications of another's honesty or mendacity. Three major themes currently exist to explain the presence of non-verbal indicators of deception, each with its own unique contribution (Vrij, 2000). First, the emotional arousal hypothesis suggests that deception produces various emotional states which may influence non-verbal signals. For example, liars may experience fear, which may contribute to nervous movements or fidgeting. Second, the cognitive hypothesis focuses on the mental work load of deception and proposes that lying requires more cognitive effort which detracts from the liar's ability to behave normally. Thirdly, the behavioral control hypothesis suggests that liars may attempt to counteract any potential signs of their deception, but in the process come off as unnatural. Thus, if a liar is trying to manage several possible verbal and non-verbal cues to their deception simultaneously, their behavior may actually appear less natural and spontaneous due to their own heightened behavioral awareness and control. For instance, researchers have found that many people believe that liars make less eye contact, increase their fidgeting, and shift their posture (Akehurst, Kohnken, Vrij, and Bull, 1996; Hart, Hudson, Fillmore, \& Griffith, 2006).

Stromwall, Granhag, and Hartwig (2004) suggested that for laypersons, the likely factors resulting in these wrongful beliefs include several psychological factors. First, the representativeness heuristic, or our tendency to assume that a sample or incident is an exemplar of the overall population, could lead people to generalize from a small set of experiences in which liars are exposed. Second, confirmation bias, the tendency to look for confirming instead of disconfirming evidence, could explain how certain misconceptions are propagated by people not looking for evidence that their beliefs are wrong. Thirdly, it is also possible that feedback plays a crucial role in our many misconceptions. For feedback to be corrective of misconceptions, it should take place often, be consistent, and happen promptly (Allwood\&Granhag, 1999; Ekman, 2001).

In two diary studies of lying by Epstein, DePaulo, Kirkendol, Kashy \& Wyer in 1996, 77 college students reported telling two lies a day, and 70 community members told one. Participants told more self-centered lies than other-oriented lies, except in dyads involving only women, in which other-oriented lies were as common as self-centered ones. Participants told relatively more selfcentered lies to men and relatively more other-oriented lies to women. Consistent with the view of lying as an everyday social interaction process, participants said that they did not regard their lies as serious and did not plan them much or worry about being caught. Still, social interactions in which lies were told were less pleasant and less intimate than those in which no lies were told.

From the current review of lying, it can be concluded that lying is a part of communication and a form of social behavior which is involved in interacting with others. Lying means saying a statement that he/she knows themselves as false to others to whom he/she want to perceive it as true. It arises from hedonistic nature of humans that to avoid pain and to increase pleasure. It can be also seen that we lies not only for personal gains but also for others gain too. That is to avoid 


\section{Psychology of Lying}

harm affecting ourselves and to avoid hurting others. So we can come to an end of the article by saying that lying can be accepted if it saves someone's life-ourselves or of others.

\section{REFERENCES}

Akehurst, L., Kohnken, G., Vrij, A., \& Bull, R. (1996). Lay persons' and police officers' beliefs regarding deceptive behaviour. Applied Cognitive Psychology, 10(6), 461-471.

Allwood, C. M., \& Granhag, P. A. (1999). Feelings of confidence and the realism of confidence judgments in everyday life. In P. Juslin, \& H. Montgomery (Eds.), Judgment and decision making: Neo-brunswikian and process-tracing approaches. (pp. 123-146). Mahwah, NJ, US: Lawrence Erlbaum Associates Publishers.

Anderson, D. E. (1999). Cognitive and motivational processes underlying truth bias. (deception detection, romantic relationships). US: ProQuest Information \& Learning.

Anderson, D. E., DePaulo, B. M., \&Ansfield, M. E. (2002). The development of deception detection skill: A longitudinal study of same-sex friends. Personality and Social Psychology Bulletin, 28(4), 536-545

Bond, C. F. J., \& DePaulo, B. M. (2006). Accuracy of deception judgments. Personality and Social Psychology Review, 10(3), 214-234

DePaulo, B. M., Lindsay, J. J., Malone, B. E., Muhlenbruck, L., Charlton, K., \& Cooper, H. (2003). Cues to deception. Psychological Bulletin, 129(1), 74-118

DePaulo, B. M., \& Kashy, D. A. (1998). Everyday lies in close and casual relationships. Journal of Personality and Social Psychology, 74(1), 63-79.

DePaulo, B. M., \& Bell, K. L. (1996). Truth and investment: Lies are told to those who care. Journal of Personality and Social Psychology, 71(4), 703-716.

Dike CC, Baranoski M, Griffith EE (2005). "Pathological lying revisited". The Journal of the American Academy of Psychiatry and the Law 33(3): 342-9. PMID 16186198. Retrieved from http://psychiatrictimes.com

Dike, Charles C. (June 1, 2008). Pathological Lying: Symptom or Disease? 25 (7). Retrieved from http://psychiatrictimes.com

Ekman, P. (2001). Telling lies: Clues to deceit in the marketplace, politics, and marriage. New York: W W Norton \& Co.

Epstein, J. A., DePaulo.B.M., Kirkendol, S.E., Kashy, D.A \& Wyer, M.M. (1996). Journal of Personality and Social Psychology. American Psychological Association, Inc. Vol. 70, No. $5,979-995$

Granhag, P. A. (2006). Rethinking implicit lie detection. Journal of Credibility Assessment and Witness Psychology. 7(3), 180-190. 


\section{Psychology of Lying}

Hart, C. L., Fillmore, D. G., \& Griffith, J. D. (2009). Indirect Detection of Deception- Looking for Change. Current Research In Social Psychology, Volume 14, No. 9

Hawker, S. (2006). Little Oxford English Dictionary ( $9^{\text {th }}$ ed.). India: Oxford University Press

Honts, C. R. (1994). Psychophysiological detection of deception. Current Directions in Psychological Science, 3(3), 77-82.

Kagan, S. (1998). Normative Ethics. Boulder: Westview Press.

Kashy, D. A., \& DePaulo, B. M. (1996). Who lies? Journal of Personality and Social Psychology, 70(5), 1037-1051.

Kupfer, J. (1982). The Moral Presumption Against Lying, Review of Metaphysics 36; 103-126

Langleben, D. D. (2008). Detection of deception with fMRI: Are we there yet? Legal and Criminological Psychology, 13, 1-9.

Marston, W. M. (1917). Systolic blood pressure symptoms of deception. Journal of Experimental Psychology, 2(2), 117-163.

National Research Council (2002). National Research Council, Committee to Review the Scientific Evidence of the Polygraph, Division of Behavioral and Social Sciences and Education. Washington, DC: The National Academies Press.

Spence, S. A. (2008). Playing devil's advocate: The case against fMRI lie detection. Legal and Criminological Psychology, 13, 11-25.

Stromwall, L. A., Granhag, P. A., \& Hartwig, M. (2004). Practitioners' beliefs about deception. In P. Granhag, \& L. Strömwall (Eds.), The detection of deception in forensic contexts. (pp. 229-250). New York: Cambridge University Press.

Vrij, A. (1995). Behavioral correlates of deception in a simulated police interview. Journal of Psychology: Interdisciplinary and Applied, 129(1), 15-28.

Vrij, A. (2000). Detecting lies and deceit: The psychology of lying and the implications for professional practice. New York: John Wiley \& Sons, Ltd.

Vrij, A., Edward, K \& Bull, R. (2001). People's insight into their own behaviour and speech content while lying. British Journal of Psychology, 92(2), 373-389.

Vrij, A \& Semin, G. R. (1996). Lie experts' beliefs about nonverbal indicators of deception. Journal of Nonverbal Behavior, 20(1), 65-80.

Vrij, A., Edward, K., Roberts, K. P., \& Bull, R. (2000). Detecting deceit via analysis of verbal and nonverbal behavior. Journal of Nonverbal Behavior, 24(4), 239-263.

Williams, B (2002). Truth and Truthfulness: An Essay in Genealogy. Princeton: Princeton University Press.

http://www.thehopeline.com/differnt-types-of-lies-and-liars/

http://addiction.lovetoknow.com/wiki/Psychology_of_lying

(C) The International Journal of Indian Psychology | 51 